Faculdade

de Ciências Econômicas UFRGS
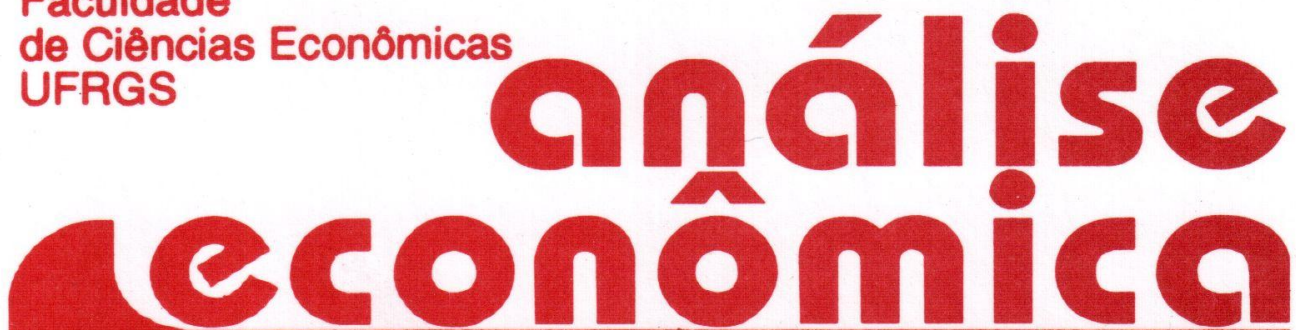

- SIDERURGIA E O PARADIGMA TECNOLÓGICO

Angela Maria Morandi

- ESTIMATING PRIVATE DEMANDS FOR PUBLIC GOODS

Eduardo Pontual Ribeiro

- KEYNES E A ATUALIDADE DA TEORIA KEYNESIANA

Fernando Ferrari Filho

- IMPRODUTIVIDADE DE UM CONCEITO DE PRODUÇÃO Raul Cristóvão dos Santos

- A NEGAÇÃo dA INEFICÁCIA DA POLÍTICA MONETÁRIA João Sicsú

- DESREgulamentAÇÃo, globa LIZAÇÃo E A CADEIA DO TRIGO Lena Lavinas

Manoel Magina

- ALUGUÉIS RESIDENCIAIS EM PORTO ALEGRE

Marco Aurélio Stumpf González

- POLICY INTERVENTION AND THE TRADE-OFF BETWEEN GROWTH AND DISTRIBUTION OF INCOME Joanílio Rodolpho Teixeira Jorge Thompson Araujo

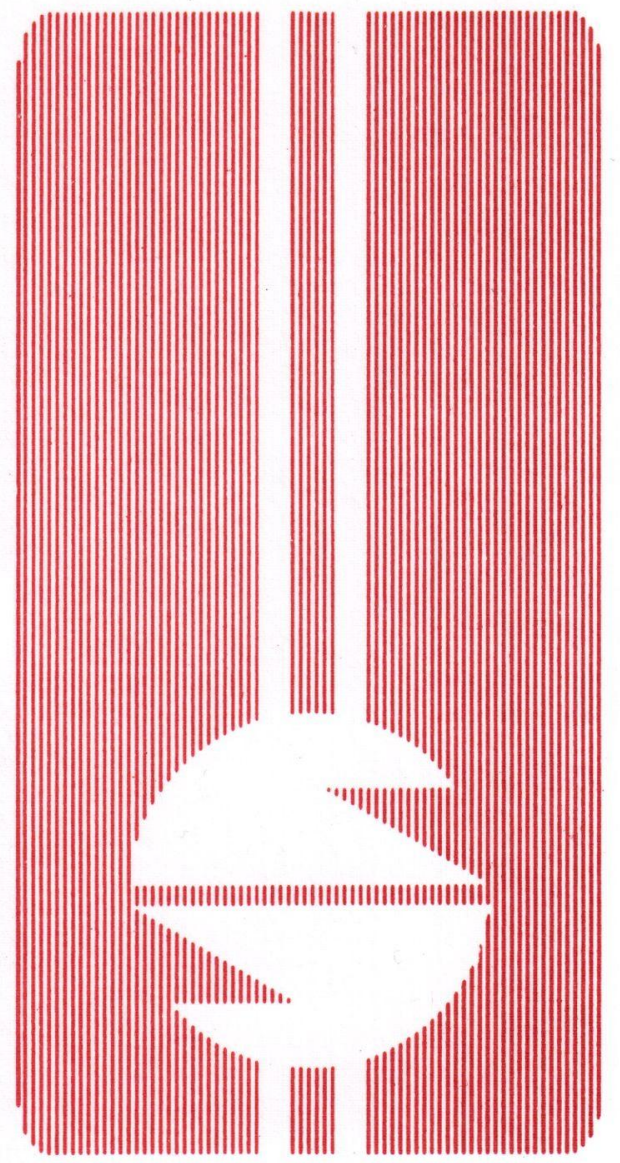


UNIVERSIDADE FEDERAL DO RIO GRANDE DO SUL

Reitora: Prof ${ }^{a}$. Wrana Maria Panizzi

FACULDADE DE CIENNCIAS ECONÓMICAS

Diretora: Prof ${ }^{\mathrm{a}}$. Otilia Beatriz Kroeff Carrion

CENTRO DE ESTUDOS E PEQUISAS ECONÔMICAS

Diretor. Prof. Fernando Ferrari Filho

DEPARTAMENTO DE CIÊNCIAS ECONÓMICAS

Chefe: Prof. Gentil Corazza

CURSO DE PÓS-GRADUAÇÃO EM ECONOMIA

Coordenador. Prof. Marcelo Savino Portugal

CURSO DE PÓS-GRADUAÇÃO EM ECONOMIA RURAL

Coordenador: Prof. Carlos Guilherme A. Mielitz Netto

CONSELHO EDITORIAL: Achyles B. Costa, Aray M. Feldens, Carlos A. Crusius, Carlos G. A. Mielitz Netto, Eduardo A. Maldonado Filho, Eduardo P. Ribeiro, Eugênio Lagemann, Fernando Ferrari Filho, Gentil Corazza, Marcelo S. Portugal, Nali J. Souza, Otília B. K. Carrion, Paulo A. Spohr, Paulo D. Waquil, Pedro C. D. Fonseca, Roberto C. Moraes, Ronald Otto Hillbrecht, Stefano Florissi, Eleutério F. S. Prado (USP), Fernando H. Barbosa (FGV/RJ), Gustavo Franco (PUC/RJ), João R. Sanson (UFSC), Joaquim P. Andrade (UnB), Juan H. Moldau (USP), Paul Davidson (Univ. of Tennessee), Werner Baer (Univ. of Illinois).

COMISSÃO EDITORIAL: Eduardo Augusto Maldonado Filho, Fernando Ferrari Filho, Gentil Corazza, Paulo Dabdab Waquil, Marcelo Savino Portugal, Roberto Camps Moraes.

EDITOR: Nali de Jesus de Souza

SECRETARIA: Cláudia Porto Silveira, Sandra Mascarello e Fábio Régis Sparremberger. Revisão de textos: Vanete Ricacheski.

FUNDADOR: Prof. Antônio Carlos Santos Rosa

Os materiais publicados na revista Análise Económica são da exclusiva responsabilidade dos autores. É permitida a reprodução total ou parcial dos trabalhos, desde que seja citada a fonte. Aceita-se permuta com revistas congêneres. Aceitam-se, também, livros para divulgação, elaboração de resenhas e recensões. Toda correspondência, material para publicação (vide normas na terceira capa), assinaturas e permutas devem ser dirigidos ao seguinte destinatário:

PROF. NALI DE JESUS DE SOUZA

Revista Análise Econômica - Av. João Pessoa, 52

CEP 90040-000 PORTO ALEGRE - RS, BRASIL

Telefones: (051) 316-3348 e 316-3440 - Fax: (051) 316-3990

nali@vortex.ufrgs.br 


\title{
KEYNES E A ATUALIDADE DA TEORIA KEYNESIANA
}

\author{
Fernando Ferrari Filho*
}

\section{SINOPSE}

O objetivo principal do artigo é mostrar como a natureza revolucionária da teoria keynesiana é desenvolvida ao longo da obra de Keynes. A partir desse objetivo, 0 artigo conclui que a discussão contemporânea em Economia não pode prescindir das análises $\theta$ proposiçōes econômicas de Keynes para explicar e, talvez, solucionar a crise de desemprego da economia mundial, em grande parte, advinda do processo de globalização da economia.

Cód. AEA: 331

Palavras-chave: Teoria keynesiana, Reforma monetária internacional, demanda efetiva desemprego.

\section{ABSTRACT}

The main purpose of this article is to show how the revolutionary character of Keynesian theory is developed in Keynes's works. Considering that, the article concludes that the debate in Economics cannot neglect the Keynes's analysis and economic proposals to explain and, maybe, solve the unemployment crisis observed in the World economy that is, basically, a consequence of the globalization process of the economy.

Key Words: Keynesian theory, Intemational monetary reform, effective demand and unemployment.

\section{INTRODUÇÃo}

O ano de 1996 foi de particular importância na história da teoria econômica: há sessenta anos era publicada a The general theory of employment, interest, and money, de agora em diante denominada $G T$, bem como cinqüenta anos atrás morreu John Maynard Keynes. As análises

Professor Titular do Departamento de Economia e Diretor do Centro de Estudos e Pesquisas Económicas da UFRGS.
ANÁLISE ECONÓMICA
ANO 15
N. 28
Setembro/97
p. $44-58$ 
político-econômicas de Keynes apresentadas enquanto ele era policy adviser do Tesouro Britânico e as concepções teóricas e prescrições econômicas contidas na $G T$ influenciaram o rumo do capitalismo no século $X X$ e revolucionaram o estudo da Economia moderna.

Desde o primeiro livro, Indian currency and finance, escrito em 1913, até o último artigo, The balance of payments of the United States, publicado em junho de 1946, após a sua morte, Keynes sempre preocupou-se em entender a natureza dos problemas econômicos das economias empresariais modernas, ${ }^{1}$ tais como instabilidades do nível de preços, flutuações cíclicas dos niveis de produto e emprego e crises do sistema monetário-financeiro internacional, e apresentar soluções para os mesmos que vão, via de regra, na direção da regulação do capitalismo por parte do Estado.

O presente artigo objetiva mostrar, cronologicamente, como a natureza revolucionária da teoria keynesiana é desenvolvida ao longo da obra de Keynes, a partir de uma dinâmica em que os fundamentos teóricos da economia clássica, quais sejam, padrão-ouro, lei de Say e teoria quantitativa da moeda, são, inicialmente, questionados e, a posteriori, rejeitados.

\section{DAS CRÍTICAS AO CAPITALISMO LIBERAL À COMPREENSÃO DA DINÂMICA DAS ECONOMIAS MONETÁRIAS: A CONSTRUÇÃO DA REVOLUÇÃO KEYNESIANA}

As atenções de Keynes acerca das questões monetárias surgem em Indian currency and finance, publicado em 1913. Nesse livro Keynes, após apresentar uma análise comparativa sobre as vantagens e desvantagens dos sistemas monetários gold standard e gold-exchange standard, expressa o seu ceticismo em relação à utilização do ouro como principal instrumento de reserva internacional de pagamentos. Tomando como referência a dinâmica do sistema monetário-financeiro indiano, Keynes propõe uma reforma monetária internacional com características semelhantes às do gold-exchange standard em que a elasticidade da liquidez internacional deva ser determinada, não conforme o comportamento de "... a lucky prospector, a new chemical process, or a change of ideas in Asia" (1913, p.101), mas sim pela sistemática de compra e venda de moedas conversiveis em relação ao ouro. Ao enfatizar a necessidade de se reestruturar o sistema monetário internacional, uma vez que a liquidez do mesmo não poderia estar sujeita à manipulação de reservas auríferas por

\footnotetext{
1 Esses, diga-se de passagem, estão comumente relacionados às questões monetárias,
} mais especificamente, ao papel que a moeda exerce nas economias capitalistas 
parte de determinados países, Keynes argumenta que o gold-exchange standard "... [that is] the use of a cheap local currency artificially maintained at par with the international currency or standard of value ... is the ideal currency of the future" (Ibid., p.36; itálicos adicionados).

A proposição de um sistema monetário em que a liquidez internacional passe a ser administrada pela política monetária nacional faz crer que Keynes, na referida obra, já questiona o mecanismo de ajustamento automático do balanço de pagamentos sob as regras do padrão-ouro.

A partir de então, as críticas ao padrão-ouro, fundamentadas em diversas propostas de reformas do sistema monetário internacional que têm como ponto central a eliminação gradual do ouro como international asset e a eficiência distributiva das reservas monetárias, tornam-se constantes nas análises de Keynes.

The economic consequences of the peace, escrito em 1920, além de ter tornado Keynes mundialmente famoso, principalmente pelo fato de que o livro apresenta veementes críticas às cláusulas do Tratado de Versailles, pode ser considerado o marco referencial de Keynes analisar e teorizar as questões econômicas. Em outras palavras, o referido livro representa a transição do pensamento ortodoxo keynesiano para as idéias originais de Keynes acerca do funcionamento da dinâmica do capitalismo moderno.

Ao discutir os problemas da economia européia imediatamente após a Primeira Guerra Mundial, Keynes escreve que "The problem of the reinauguration of the perpetual circle of production and exchange in foreign trade leads me to a necessary digression on the currency situation of Europe" (1920, p.235).

A digressão de Keynes pertinente à situação monetária da Europa vai ao encontro de uma frase atribuída a Lenin de que a melhor maneira de destruir o sistema capitalista é a destruição de sua moeda. Lenin, afirma Keynes, "... was certainly right. There is no subtler, no surer means of overturning the existing of basis of society than to debauch the currency" (lbid., p.236). Para Keynes, as crises monetárias, especialmente as de natureza inflacionária, afetam a base institucional do capitalismo, qual seja, as relações contratuais entre os indivíduos e as instituições.

Preocupado com a reconstrução da economia européia e a redinamização do capitalismo, Keynes apresenta um conjunto de propostas que vão de encontro às proposições político-econômicas predominantes:

(a) revisão do Tratado de Versailles, principalmente das questões pertinentes às reparações de guerra;

(b) reorganização do comércio internacional a partir de uma Free Trade Union;

(c) reforma monetária internacional, tendo como referência um "fundo de empréstimo", para estabilizar as taxas de câmbio; e 
(d) manutenção das relações comercial-financeiras com todos os países da Europa.

Se essas medidas não fossem adotadas, escreve Keynes, "[t]he bankruptcy and decay of Europe ... [will] affect every one in the long run, but perhaps not in a way that is striking or immediate" (Ibid., p.296).

Otimista quanto às mudanças de opinião, Keynes dedica o livro à "... the true voice of the new generation has not yet spoken, and silent opinion is not yet formed" (Ibid., p.298).

Nos anos 20 as questões econômicas discutidas por Keynes têm como essência críticas relacionadas tanto à consistência teórica da teoria quantitativa da moeda quanto à lógica do funcionamento do capitalismo liberal.

Em A tract on monetary reform, publicado em 1923, Keynes, então preocupado em entender os problemas hiperinflacionários e de flutuações cambiais observados na Europa de pós-Guerra, realiza uma discussão teórica sobre politica monetária, a partir de uma reinterpretação da equação quantitativa de Cambridge.

Inicialmente, Keynes discute as conseqüências para a sociedade quando há variações no valor da moeda, uma vez que "... when the value of money changes, it does not change equally for all persons or for all purposes" (1971, p.1). Nesse particular, a conclusão de Keynes é que

Each process, inflation and deflation .... has an effect in altering the distribution of Wealth between different classes, inflation in this respect being the worse of the two. Each has also an effect in overstimulating or retarding the production of Wealth, though here deflation is the more injurious (lbid., p.3).

Se variações no valor da moeda afetam as naturezas distributiva e produtiva da economia, o passo seguinte consiste em mostrar que, em algum determinado momento, a teoria quantitativa da moeda apresenta uma inconsistência lógica. ${ }^{2}$ Essa questão é analisada ao longo do capítulo 3 do Tract. Após "endogenizar" a velocidade de circulação da moeda, reformulando, assim, a equação quantitativa de Cambridge, ${ }^{3}$ Keynes argumenta que os hábitos do público em demandar moeda e a sistemática operacional do sistema bancário em relação às suas reservas monetárias afetam a proporcionalidade entre meios de pagamento e nível de preços, essência da teoria monetária ortodoxa. Nas palavras dele,

\footnotetext{
${ }^{2}$ Pela análise de Keynes, a inconsistência lógica da teoria quantitativa da moeda está relacionada ao fato de que nem sempre existe uma proporcionalidade entre meios de pagamento e nivel de preços, conforme atesta a referida teoria.

${ }^{3}$ Cabe ressaltar que a reestruturação da equação quantitativa da moeda não tem como objetivo refutá-la, mas sim torná-la dinámica, uma vez que Keynes entende que "[t]his theory is fundamental. Its correspondence with fact is not open to question" (1971, p.61).
} 
... an arbitrary doubling of $n$ [money supply], since this in itself is assumed not to affect $k$ [demand for money in terms of cash], $r$ [the relation between the amount of cash the banks keep and their potential liabilities], and $k^{\prime}$ [demand for money in terms of deposits at commercial banks], must have the effect of raising $p$ [price level] to double ... Now 'in the long run' this is probably true" (Ibid., p.65).

Porém, continua Keynes, "... this long run is a misleading guide to current affairs. In the long run we are all dead" (Ibid., p.65).

A metáfora na passagem acima está relacionada ao fato de que, no curto prazo, variações no estoque monetário influenciam os comportamentos do público e das instituições bancárias em relação às suas decisões de demanda por moeda e manutenção de reservas monetárias, respectivamente. Segundo Keynes,

after, during, and ... before a change in the value of $n$, there will be some reaction on the values of $k, k$, and $r$, with the result that the change in the value of $p$, at least temporarily and perhaps permanently . will not be precisely in proportion to the change in $n$ (lbid., p.66-7).

\section{A "moral da discussão", conclui Keynes,}

is that the price level is not mysterious, but is governed by a few, definite, analyzable influences. Two of these, $n$ and $r$, are under the direct control ... of the central banking authorities. The third, namely, $k$ and $k$ ', is not directly controllable, and depends on the mood of the public and the business World (lbid., p68).

Se money matters, pelo menos no curto prazo, então regras de administração monetária, visando às estabilidades dos niveis de preços, produto e emprego e taxa de câmbio, constituem-se na solução keynesiana. Para tanto, segundo Keynes, a estabilidade monetária “ ... consists partly in exercising a stabilising influence over $k$ and $k$, and ... deliberately varying $n$ and $r$ " (Ibid., p.68). Nesse contexto, Keynes entende que "... the objective of the authorities ... should be the stability of prices" (Ibid., p.149).

Como se percebe, o Tract introduz algumas questões, entre as quais, o papel das expectativas e da coordenação no processo de decisões econômicas, que serão de fundamental importância para a compreensão da teoria monetária da produção, elaborada por Keynes nos anos 30.

Quando o Tesouro Britânico resolve restaurar, em abril de 1925, o sistema padrão-ouro na Inglaterra, à paridade cambial vigente no período de pré-Guerra, a reação de Keynes é imediata: em julho ele escreve um, artigo, intitulado The economic consequences of Mr.Churchill, criticando, veementemente, essa decisão.

A argumentação de Keynes está fundamentada no fato de que a sobrevalorização da libra esterlina, conseqüência imediata da referida 
medida, tende a provocar "... a general fall of all internal prices and wages" (1972, p.208) cujo "... result is both to encourage imports and to discourage exports, thus turning the balance trade against us [England]"(Ibid., p.216). Mais especificamente, Keynes está preocupado em mostrar que a apreciação cambial tem como efeito a deflação e, por conseguinte, o desemprego. Nas palavras dele, o modus operandi da taxa de câmbio sobrevalorizada resulta "[i]n no other way than by the deliberate intensification of unemployment ... Deflation does not reduce wages 'automatically'. It reduces them by causing unemployment" (Ibid., p.218-20).

Naquela ocasião, a solução keynesiana para evitar a depressão da economia inglesa está relacionada a uma questão que Keynes, há alguns anos, já vinha advogando, qual seja, a Inglaterra deveria, uma vez por todas, abandonar o sistema monetário padrão-ouro. A passagem a seguir ilustra, implicitamente, essa idéia:

The gold standard, with its dependence on pure chance, its faith in 'automatic adjustments', and its general regardlessness of social detail, is an essential emblem and idol of those who sit in the top of the machine. I think that they are immensely rash in regardlessness, in their vague optimism and comfortable belief that nothing really serious ever happens. Nine times out of ten, nothing really serious does happen - merely a little distress to individuals or to groups. But we run a risk of the tenth time (and are stupid into the bargain), if we continue to apply the principles of an Economics, which was worked out on the hypotheses of laissez-faire and free competition, to a society which is rapidly abandoning these hypotheses (lbid., p. 224).

A citação acima mostra o ceticismo de Keynes não somente em relação à lógica do processo de ajustamento automático do balanço de pagamentos sob as regras do padrão-ouro - diga-se de passagem, já questionado por Keynes em Indian currency and finance, conforme foi discutido anteriormente -, mas, também, no que diz respeito à sistemática operacional do capitalismo liberal como solução para os problemas econômicos.

As críticas pertinentes ao capitalismo liberal são objeto de análise em The end of laissez-faire, publicado em 1926. Em uma das passagens do referido artigo, Keynes escreve que

... devotees of capitalism are often unduly conservative, and reject reforms in its technique ... Nevertheless, a time may be coming when we shall get clearer than at present as to when are talking about capitalism as an efficient or inefficient technique, and when we are talking about it as desirable or objectionable in itself. For my part 1 think that capitalism, wisely managed, can probably be made more efficient for attaining economic ends than any atternative system yet in sight ... Our problem is to work out a social organization which shall be as efficient as possible ... (lbid., p.294; itálico adicionado). 
A passagem acima sugere que Keynes já está preocupado em encontrar mecanismos institucionais que viabilizem a dinâmica de um capitalismo administrado. Em outras palavras, a nosso juízo, a citação deixa implícito que Keynes já tem ciência de que um capitalismo razoável passa, necessariamente, pela "mão visível" do Estado, regulando as disfunções sócio-econômicas do capitalismo. No final dos anos 20 as atenções de Keynes estão divididas, por um lado, com o seu trabalho junto ao Macmillan Committee ${ }^{4}$ e, por outro, com a elaboração de seu livro $A$ treatise on money, editado em 1930.

As discussões mantidas entre os membros da referida comissão acerca de qual deveria ser a melhor estratégia de condução da política econômica inglesa, no contexto da economia internacional, contribuíram para que Keynes mudasse a sua posição sobre política comercial: ele passa a propor, como política de emprego, a adoção de práticas protecionistas, sob a forma de revenue tariff. As seguintes citações ilustram essa idéia:

\begin{abstract}
I am almost ... clear that there are certain short-run advantages in protection .... It is a very difficult position to meet.... It is extremely difficult for anyone of free trade origin ..." $(1981$, p 120$)$. I have, therefore, become reluctantly convinced that some protectionist measures should be introduced ... I am no longer a free trader ... in the old sense of the term to the extent of believing in a very high degree of national specialization and in abandoning any industry which is unable for the time being to hold its own (lbid., p.378-9).
\end{abstract}

O que leva Keynes a abandonar as suas origens de free trade? A explicação está, por um lado, relacionada a uma questão pragmática: tarifas, por serem mais flexiveis do que taxa de câmbio, tornam-se um importante instrumento para compensar a sobrevalorização cambial, advinda com o retorno da Inglaterra ao sistema padrão-ouro. Por outro, Keynes argumenta que o livre comércio, tendo como suposição condições de equilíbrio que sempre necessitam oscilações de preços e salários, não é um mecanismo eficiente para solucionar crises de desemprego quando, face ao poder de barganha dos trabalhadores, os salários nominais são rígidos ${ }^{5}$

As idéias do Treatise são apresentadas em dois volumes: The pure theory of money, volume inicial, analisa os problemas monetários em um contexto no qual a economia move-se de uma situação de equilibrio para outra. O segundo volume, The applied theory of money, discute 0 comportamento dos sistemas monetário-financeiros nacional e

\footnotetext{
${ }^{4}$ As análises e propostas de Keynes apresentadas na Comissäo Macmillan encontram-se em Keynes (1981).

${ }^{5}$ Essa idéia, inflexibilidade do salário nominal, diga-se de passagem, é discutida, anos mais tarde, na $G T$.
} 
internacional.

As discussões no primeiro volume do Treatise têm como essência as "equações fundamentais" keynesianas que analisam a relação entre os custos de produção por unidade de produto e os preços de mercado. Esses, por sua vez, a partir de algumas definições especificas formuladas por Keynes, dependem dos níveis de poupança e investimento, das decisões do público em reter ou não moeda e do montante de saving deposits criados pelo sistema financeiro.

Tendo como referência as referidas equações, Keynes argumenta que a economia encontra-se em equilibrio de pleno emprego quando

$\ldots$ the public is neither bullish nor bearish of securities and is maintaining in the form of savings-deposits neither more nor less than the 'normal' proportion of its total Wealth, and the volume of saving is equal both to the cost and to the value of new investment ... $(1976$, v.1, p.146-7).

O que faz a economia afastar-se da posição de equilíbrio de pleno emprego? A taxa de juros, segundo Keynes, "... is the instrument by which a disturbance is set up ... between the rates of Saving and of Investment; for to raise it stimulates the one and retards the other, and conversely if it is reduced" (Ibid., p.185).

Sendo a taxa de juros o instrumento que desestabiliza o sistema econômico, Keynes, após classificar as esferas de circulação do capital em industrial e financeira, ${ }^{6}$ entende que a solução para restaurar o equilíbrio das "equações fundamentais", mantendo, por conseguinte, a economia em sua condição de pleno emprego, reside "... in letting both Finance and Industry have all the money they want, but at a rate of interest which in its effect on the rate of new investment (relatively to saving) exactly the effect of bullish sentiment" (Ibid., p.254-5).

Nesse contexto, a administração da política monetária por parte do Banco Central, seja estimulando o nivel de investimento e eliminando o excesso de poupança, seja postergando as decisões de investir e induzindo o público a poupar, constitui-se no mecanismo keynesiano para dinamizar os níveis de produto e emprego e estabilizar o nivel de preços.

No Treatise, portanto, Keynes, ao restringir a teoria quantitativa da moeda à situação de pleno emprego, apresenta uma teoria monetária em que a moeda passa a afetar a dinâmica comportamental dos agentes econômicos e, por conseguinte, da natureza produtiva da economia. Dessa

${ }^{6}$ Segundo Keynes, a esfera industrial do capital está relacionada à quantidade de moeda destinada ao processo produtivo, ao passo que o capital financeiro diz respeito à quantidade de moeda que tem como destino as atividades do sistema monetário-financeiro (1976, v.1, p. 243). 
maneira, Keynes começa a trabalhar nas linhas de sua teoria monetária da produção.

No volume dois do Treatise Keynes reconsidera a sua posição sobre o gold-exchange standard tanto em termos práticos quanto teóricos. Entendendo que, definitivamente, "... the gold standard is ... part of the apparatus of Conservatism" (1976, v.2, p.300), Keynes propõe a criação de uma autoridade monetária mundial, denominada Supernational Bank-Money (SBM), para controlar o ciclo de crédito e administrar e estabilizar o valor das reservas internacionais a partir de um padrão internacional de preços. As questões sobre o SBM são, por sua vez, apresentadas em duas propostas: mínima, também chamada prática, e máxima, entendida como proposta teórica.

As principais medidas sugeridas por Keynes em sua proposta mínima dizem respeito à proibição dos paises em manter ouro nos seus ativos de circulação, à concordância dos bancos centrais em ter, em suas reservas monetárias, algum ativo substituto para o ouro e à fixação da taxa de câmbio (lbid., p.395-8).

Por outro lado, em termos teóricos, Keynes propõe que (a) as reservas internacionais dos bancos centrais sejam constituídas por ouro e certificados de empréstimos, denominados SBM, (b) o SBM seja comercializado com o ouro a um preço fixo, sendo possível, todavia, variações mínimas de seus preços de compra e venda em relação à paridade inicial, (c) o SBM estabeleça uma taxa de juros específica a incidir sobre os empréstimos requeridos pelos bancos centrais junto ao mesmo, (d) o SBM tenha o poder de realizar operações de open market pela compra e venda de certificados de curto e longo prazos dos bancos centrais, (e) o SBM mantenha a estabilidade do valor do ouro em relação ao Tabular Standard, constituído por um conjunto de mercadorias transacionadas no comércio internacional, e $(f)$ o SBM crie mecanismos para evitar as crises inflacionárias e deflacionárias (Ibid., p.399-401).

Implementadas essas medidas, escreve Keynes, “... the Central Banks of the world would, I think, have an instrument to their hands with which the major objectivies could be attained if they chose, and knew, to use it" (lbid., p.402).

É importante ressaltar que a idéia da criação de um banco central internacional autônomo, cujos objetivos são manter a estabilidade do nivel geral de preços e financiar a demanda efetiva mundial, se constitui na essência da proposta de reforma monetária internacional preconizada por Keynes nos anos 40.

A reação no meio acadêmico em relação ao Treatise frustrou as expectativas iniciais de Keynes: o livro não obteve êxito e, muito pelo contrário, foi alvo de inúmeras críticas. Entre essas, sem dúvida nenhuma, 
as sugestões apresentadas por um grupo de jovens economistas, entre os quais, J.Robinson, J.Meade, R.Khan, P.Sraffa e R.Harrod, que integravam o chamado "circo" de Cambridge ${ }^{7}$, foram de, fundamental importância para que Keynes começasse a trabalhar naquele que constituir-se-ía, anos mais tarde, no seu principal livro: GT.

Como se sabe, o projeto de Keynes na GT consiste em, por um lado, negar o sistema econômico de mercados auto-equilibrantes e, por outro, apresentar mecanismos econômicos que evitem as flutuações cíclicas dos niveis de produto e emprego. Para tanto, Keynes desenvolve seu projeto em torno do princípio da demanda efetiva que pode ser decomposto em três proposições teóricas: teoria da função consumo (propensão a consumir), teoria do investimento (eficiência marginal do capital) e teoria da taxa de juros (preferência pela liquidez).

A partir das referidas teorias, a análise keynesiana desenvolve-se dentro de um contexto no qual a dinâmica dos ciclos econômicos é explicada pela natureza monetária. Nas palavras de Keynes, “... booms and depressions are phenomena peculiar to an economy in which ... money is not neutraf' (1973, p. 411; itálicos adicionados). No capitulo $17 \mathrm{da} \mathrm{GT}$, as argumentações de Keynes vão nessa direção: as crises de demanda efetiva e, por conseguinte, desemprego, manifestam-se porque os individuos, face à incerteza em relação ao futuro, retêm moeda em seus encaixes reais, postergando, assim, quaisquer decisões de consumo e investimento.

Por que os indivíduos preferem reter moeda? A explicação está relacionada às propriedades essenciais que a moeda possui, diferenciandoa, assim, dos outros ativos: por um lado, sua elasticidade de produção é zero - isto é, moeda não é produzida pela quantidade de trabalho que o setor privado incorpora no processo produtivo; por outro, a elasticidade substituição da moeda é zero - em outras palavras, nenhum outro ativo produzido por trabalho substitui a moeda como reserva de valor. Diante dessas propriedades, Keynes diz que

Unemployment develops .... because people want the moon; - men cannot be employed when the object of desire (i.e money) is something which cannot be produced and the demand for which cannot be readily choked off $(1964$, p. 235).

As idéias acima convergem para a concepção keynesiana de teoria monetária da produção. Isto é, havendo inexistência do conhecimento, por parte dos agentes econômicos, dos planos de produção, consumo e transações, a moeda deixa de ser neutra - seja por representar um elo com as relações reais, seja porque se constitui na defesa contra a incerteza

\footnotetext{
7 No que diz respeito às críticas do "circo" de Cambridge, veja o capítulo 20 de Moggridge (1992)
} 
acerca do futuro - e, por conseqüência, sua demanda condiciona a dinâmica do processo produtivo. Assim sendo, as crises de demanda efetiva se manifestam e, com elas, o desemprego surge.

Qual é a solução keynesiana para a insuficiência de demanda efetiva? Uma vez que "There is ... no ground for belief that ... an open-market monetary policy is capable ... [to keep] the economic system ... selfadjusting along [this line]" (Ibid., p.267; itálico adicionado) - ou seja, visto que a política monetária não consegue persuadir os agentes econômicos a livrarem-se de moeda, revertendo, assim, suas decisões de gastos -, bem como a flexibilidade dos salários nominais não é condição, seja necessária, seja suficiente, para manter a economia em pleno emprego, ${ }^{8}$ o "Estado organizado" constitui-se na solução keynesiana para criar demanda efetiva $e$, conseqüentemente, expandir os niveis de produto e emprego. Nas palavras de Keynes, "I conceive ... that a somewhat comprehensive socialisation of investment will prove the only means of securing an approximation to full employment" (Ibid., p.378).

Nesse particular, torna-se importante mencionar que as políticas de demanda efetiva de cunho keynesiana nortearam a dinâmica da economia mundial entre os anos que vão do período imediatamente após a Segunda Guerra Mundial até o início da década de 70. Cabe ressaltar, ainda, que durante o referido período os resultados econômicos, sejam pertinentes à estabilidade dos preços internacionais, sejam relacionados ao crescimento do Produto Interno Bruto mundial, foram os mais auspiciosos ao longo de toda a história econômica contemporânea.

No final dos anos 30 e início dos 40 , Keynes, ao retomar suas funções de assessor do Tesouro Britânico, torna-se o principal articulador do governo inglês tanto para questões pertinentes aos financiamentos interno e externo da Inglaterra, durante a Segunda Guerra Mundial, quanto para questões acerca da reorganização do sistema monetário internacional. São desse período o artigo How to pay for the war, escrito em 1940, e a sua proposta de reestruturação do sistema monetário internacional, denominada Poposals for an International Clearing Union.

Em How to pay for the war, Keynes procura responder à seguinte questão: como é possível financiar os gastos de guerra sem, contudo, criar pressões inflacionárias na economia? Ciente de que, em período de guerra, as restrições quantitativas não são de demanda, Keynes apresenta uma proposta, denominada Compulsory Saving, relacionada à natureza distributiva da renda que tente "... to reconcile the demands of war and the

\footnotetext{
${ }^{8}$ Segundo Keynes, "... the Classical Theory has been accustomed to rest the supposedly self-adjusting character of the economic on an assumed fluidity of money-wages; and, when there is rigidity, to lay on this rigidity the blame of maladjustment ... My difference from this theory is primarily a difference of analysis" (1964, p 257; italicos adicionados).
} 
claims of private consumption"(1972, p.367). A despeito das reações contrárias à sua proposta, principalmente pelo fato de que ela impunha sacrificios à maioria da população, Keynes entende que essa "... embodies an advance towards economic equaiity than any which we have made in recent times" (Ibid., p.368).

É importante assinalar que na referida obra Keynes discute a política fiscal não somente como instrumento de dinamização da demanda efetiva, mas, principalmente, como mecanismo de distribuição da renda. Nesse sentido, a idéia de um capitalismo social parece estar inserida no contexto político-filosófico do "velho" Keynes, o que vai de encontro às apologias sobre o capitalismo liberal, então manifestadas pelo "jovern" Keynes.

Em Proposals for an International Clearing Union, Keynes, então preocupado com o rumo das crises monetário-financeira e comercial, em escala mundial, dinamizadas durante a guerra, propõe a criação de regras e instituições monetárias centralizadas para garantir um mínimo de previsibilidade às decisões privadas das economias nacionais. Nesse particular, Keynes apresenta um conjunto de propostas relativas às questões (a) monetárias e cambiais, (b) de regulação da política comercial, (c) de reestruturação dos processos de produção, distribuição e de determinação dos preços dos produtos primários, e (d) de financiamento dos investimentos futuros $(1980, p .233-4),{ }^{9}$ objetivando, dessa maneira, prevenir a insuficiência de demanda efetiva, controlar os movimentos de capitais e assegurar a liquidez internacional necessária para estabilizar o nivel de preços.

Essas idéias, como se sabe, apesar de terem sido vencidas quando das discussões acerca da reorganização do sistema monetário internacional de pós-Guerra, articulada durante a Conferência de Bretton Woods, em 1944, influenciaram a dinâmica da ordem econômica internacional vigente até 0 inicio dos anos 70.

Em 1946, em seu último artigo, The balance of payments of the united States, Keynes argumenta que o dólar somente poderia exercer as

${ }^{9}$ Entre essas, sem dúvida nenhurna, as discussões monetárias e cambiais merecem destaque na análise de Keynes. Segundo ele,

"We need a quantum of International currency, which is neither determined in an unpredictable and irrelevant manner as, for example, by the technical progress of the gold industry, nor subject to large variations depending on the gold reserve policies of individual countries; but is governed by the actual current requirements of World commerce, and is also capable of detiberate expansion and contracion to offset deflationary and inflationary tendencies in effective World demand" (1980, p. 168-9).

Nesse particular, Keynes propõe a criação de "... a Currency Union, here designated an International Clearing Union, based on International bank money, called ... bancor, fixed (but not unalterably) in terms of gold ..." (Ibid., p168-9). 
funções de circulação mundial e reserva de valor desde que os Estados Unidos, em um contexto de regra de conversibilidade dólar-ouro, emitissem moeda na proporção em que acumulassem reservas em seus balanços de pagamentos. A preocupação de Keynes tornou-se, anos mais tarde, pertinente uma vez que os Estados Unidos passaram a financiar, através de seus recorrentes déficits em transações correntes, a recuperação da economia mundial no pós-Guerra. Em outras palavras, Keynes, implicitamente, chamava a atenção das possíveis fragilidade do mecanismo de administração das reservas monetárias internacionais e instabilização das taxas de câmbio que poderiam ocorrer quando a emissão da moeda norte-americana não tivesse como lastro o ouro. ${ }^{10}$

\section{3. À GUISA DE CONCLUSÃO}

Como se sabe, o crescimento da internacionalização da produção e do sistema financeiro desde os anos 60 , processo denominado globalização, tem alterado substancialmente a natureza e os determinantes da dinâmica econômica internacional. Nesse contexto, a teoria do mainstream tem, por um lado, expressado, reiteradamente, o ponto de vista de que as idéias de Keynes e as politicas econômicas keynesianas fazem parte do passado. Por outro, ela tem centrado a discussão em Economia em torno do capitalismo (neo)liberal, cujos princípios econômicos básicos são a desregulamentação dos mercados, a flexibilização de preços, o livremercado e as privatizações, entre outros, que, inequivocamente, ao resgatar os fundamentos teóricos da economia clássica, restringem a ação econômica do Estado Nacional.

Passadas algumas décadas da publicação da $G T$ e da morte de Keynes, será que as idéias revolucionárias de Keynes tornaram-se irrelevantes para a compreensão e solução dos problemas econômicos contemporâneos?

A análise revolucionária de Keynes procura tanto explicar a dinâmica das economias empresariais quanto apresentar mecanismos que solucionem as suas crises econômicas. No que diz respeito à análise explicativa do funcionamento das economias empresariais, Keynes mostra que nessas as crises de desemprego são constantes porque moeda afeta, tanto no curto quanto no longo prazos, as decisões de gastos dos indivíduos (moeda não é neutra). Por outro lado, as soluções keynesianas para as

\footnotetext{
${ }^{10}$ Como se sabe, o processo de "financeirização" do capital, caracterizado pelas mobilidade de capital, volatilidade da taxa de câmbio e inovaçóes financeiras, que, diga-se de passagem, pōem em cheque as politicas macroeconômicas nacionais, originou-se, em grande parte, a partir da crise do dólar e, por conseguinte, da ruptura unilateral dos Estados Unidos com a regra de conversibilidade dólar-ouro estabelecida em Bretton Woods.
} 
flutuações cíclicas da economia vão na direção da regulação do sistema econômico.

Tendo como referência as considerações do parágrafo anterior, bem como entendendo que a teoria do mainstream, apesar do grau de sofisticação de sua estrutura teórico-analítica, não tem uma explicação consistente para as crises de desemprego ${ }^{11}$ é difícil aceitar a idéia de que a teoria keynesiana é parte do passado, principalmente quando se sabe que a expansão capitalista do período de pós-Segunda Guerra Mundial até meados dos anos 70, alicerçada em políticas macroeconômicas keynesianas, demonstra que, em nenhum outro período da história econômica, os resultados econômicos, sob as óticas de taxas de crescimento do produto e do nível de emprego, de comportamento inflacionário e de estabilidades de taxas de juros e de câmbio, foram tão favoráveis. Keynes, décadas atrás, mostrou seu ceticismo em relação à teoria econômica hegemônica como teoria explicativa dos níveis de determinação da renda e do emprego. Nas palavras dele, "... the weight of my criticism is desired against the inadequacy of the theoretical foundations of the laissez-faire doctrine upon which I was brought up and which for may years I taught ..." (1964, p.339).

Contrariamente à idéia de obsoletismo da teoria keynesiana, o artigo, ao mostrar como a análise revolucionária de Keynes é desenvolvida ao longo de sua obra, ilustra, de certa maneira, a atualidade das idéias de Keynes para explicar e, talvez, solucionar as crises das economias empresariais no real world. Nesse sentido, por mais que no "longo prazo todos estejam mortos", o debate em Economia não pode prescindir da longevidade da revolução keynesiana, principalmente quando o capitalismo (neo)liberal, atualmente em curso na economia mundial, impõe dificuldades adicionais à geração de emprego.

\section{BIBLIOGRAFIA}

KEYNES, J M Indian currency and finance. London: Macmillan, 1913. 1920 .

The economic consequences of the peace. New York: Harcourt. Brace and Howe,

The balance of payments of the United States. Economic Journal, V. LVI (222),

p.172-87, June, 1946

The general theory of employment, interest, and money New York: HBJ Book, 1964

A tract on monetary reform. London: Macmillan (The Collected Writings of John

Maynard Keynes, v 4), 1971.

11 Por exemplo, as teorias macroeconômicas novo-clássica e novo-keynesiana procuram explicar as flutuações ciclicas dos níveis de produto e emprego como decorrentes da escolha intertemporal entre renda e lazer dos individuos e da rigidez de preços e salários, respectivamente. 
Essays in persuasion London: Macmillan (The Collected Writings of John Maynard Keynes, v.9), 1972

The general theory and after part I, preparation. London: Macmillan (The Collected Writings of John Maynard Keynes, edited by D.Moggridge, v. 13), 1973. A treatise on money New York: AMS, 1976

Activities 1940-4 shaping the post-War World - the Clearing Union. London: Macmillan (The Collected Writings of John Maynard Keynes, edited by D Moggridge, v.25), 1980 .

Activities 1929-31: rethinking employment and unemployment policies. London, Macmillan (The Collected Writings of John Maynard Keynes, edited by D.Moggridge, V.20), 1981

MOGGRIDGE, D. Maynard Keynes an economist's biography. London: Routledge, 1992.

SKIDELSKY, R. John Maynard Keynes: hopes betrayed, 1883-1920. London: Macmillan, 1983. 1992.

John Maynard Keynes the economist as savior, 1920-1937. London Macmillan, 